DOI: https://doi.org/10.15407/techned2018.05 $: \underline{065}$

\title{
DESIGN OF THE ELECTRIC MOTOR WITH PERMANENT MAGNETS FOR ELECTRIC VEHICLE ACCORDING THE DRIVING CYCLE
}

Journal

Publisher

ISSN

Issue

Pages
Tekhnichna elektrodynamika

Institute of Electrodynamics National Academy of Science of Ukraine 1607-7970 (print), 2218-1903 (online)

No 5, 2018 (September/October)

$65-68$

\section{Authors}

\section{V.V. Grebenikov ${ }^{\star}$, M.V. Priymak ${ }^{*}$}

Institute of Electrodynamics National Academy of Sciences of Ukraine,

pr. Peremohy, 56, Kyiv, 03057, Ukraine,

e-mail: elm1153@gmail.com

* ORCID ID : http://orcid.org/0000-0002-1114-1218

** ORCID ID : https://orcid.org/0000-0002-1383-232X

The results of modeling a permanent magnet motor are given, which can be used instead of an internal combustion engine for mini cars. The dimensions of the magnetic system of the electric motor and the values of the electromagnetic torque are determined, taking into account the mass and dimensions parameters of the electric vehicle and the European driving cycle. The optimal thickness of the magnets is determined, at which the specified value of the electromagnetic moment is ensured, as well as the optimum performance of the circulation pump, at which a given current density and optimal liquid cooling are provided. All calculations are performed in MotorSolve and Magnet, provided by Infolytica. References 4, figures 6. 
Key words: electric motor with permanent magnets, driving cycle, optimal geometry of the rotor.

Received: 05.03 .2018

Accepted: 20.03.2018

Published: 16.08.2018

\section{References}

1. Lazari P., Wang J., Chen L. A. Computationally Efficient Design Technique for Electric-Vehicle Traction Machines. IEEE Transactions on Industry Applications. 2014. Vol. 13. No 5. Pp. 3203-3213.

2. Chen L., Wang J., Lazari P., Chen X. Optimizations of a permanent magnet machine targeting different driving cycles for electric vehicles. International Electric Machines \& Drives Conference, IEEE Internationa I. May 12-15, 2013. Chicago, Illinois, USA. Pp. 855-862.

3. Vaskovskyi Yu.M., Haidenko Yu.A., Rusiatynskyi A.E. Mathematical modeling and selecting of construction parameters for traction synchronous motors with permanent magnets. Tekhnich na Elektrodynamika 2013. No 6. C. 40-45. (Rus)

4. Grebenikov V.V., Priymak M.V. Comparative analysis of magnetic electric motors with permanent magnets for electric buses. Visnyk NTU KhPI. Seriia: Elektrychni mashyny ta elektromekhanichne peretvorennia enerhii . 2016. Vol. 11 (1183). Pp. 42-46. (Rus)

PDF 